\title{
EPMA Characterization of Residual Al Content in Oxidized High-Temperature Alloys
}

\author{
B. A. Pint, * L. R. Walker* and I. G. Wright* \\ * Oak Ridge National Laboratory, PO Box 2008, Oak Ridge, TN 37831-6156
}

Recent interest in modeling the high-temperature oxidation behavior of alloys in an attempt to better predict their oxidation-limited lifetimes has identified several critical parameters and their influence on the accuracy of the prediction.[1-2] Essentially, lifetime can be correlated to the time required for the concentration at the alloy-oxide interface of the elements required to form the protective oxide scale (usually $\mathrm{Cr}$ or $\mathrm{Al}$ ) to fall to some critical level $\left(C_{b}\right)$ at which protection breaks down. The difference between the starting content and $C_{b}$ along with the component thickness defines the available reservoir, thus it is essential to determine $C_{b}$ in order to accurately model oxidation behavior. This critical concentration is different from that calculated from thermodynamic considerations because of the kinetic factors involved in the growth of the oxide scale and interdiffusion in the alloy. Growth of the oxide results in preferential consumption of the element of interest and its depletion from the alloy surface regions. If the rate of removal by oxidation is faster than the rate of diffusion of the element from the bulk of the alloy, then a concentration gradient will develop. However, for alloys designed to form alumina scales at high temperatures, such as Haynes alloy 214 ( $\mathrm{NiCrAl}), \mathrm{FeCrAl}$-based alloys and iron aluminides $\left(\mathrm{Fe}_{3} \mathrm{Al}\right)$ [3-4], the rate of diffusion of $\mathrm{Al}$ in the alloy typically is faster than the oxidation rate, so that essentially no concentration gradient in $\mathrm{Al}$ is developed and all of the $\mathrm{Al}$ in the alloy in excess of $C_{b}$ is available to form protective oxide. The value of $C_{b}$ potentially changes depending on the alloy composition, microstructure, processing method (cast vs. oxide-dispersed) and exposure temperature.

This study has been undertaken to measure $C_{b}$ values in various alumina-forming alloys after longterm oxidation exposures which resulted in the breakdown of the alumina scale. Specimens varying in thickness from $0.5-2 \mathrm{~mm}$ to foils $\left(40-125 \mu \mathrm{m}\right.$ thickness) were exposed at $1050^{\circ}-1300^{\circ} \mathrm{C}$ in air or $\mathrm{O}_{2}$ in standard cycles either $1 \mathrm{~h}$ or $100 \mathrm{~h}$ in duration. After exposure, the specimens were Cu-plated and metallographically sectioned for analysis by electron probe microanalysis (EPMA). Figures 1 and 2 show examples of some of the profiles measured. Table I summarizes the measured $C_{b}$ values for two commercial oxide dispersion strengthened (ODS) FeCrAl alloys (Special Metals MA956 and Plansee PM200), ingot-processed FeCrAl alloys and an ORNL ODS iron aluminide. In order to improve alumina scale adhesion, the ODS alloys all have an yttrium oxide dispersion and the ingot-processed FeCrAl contains either $\mathrm{Y}$ or $\mathrm{Ce}$ and $\mathrm{La}$ (mischmetal). The ingot-processed $\mathrm{FeCrAl}$ had no residual $\mathrm{Al}$ content after testing. The full use of the $\mathrm{Al}$ reservoir led to exceptionally long lifetimes for this class of materials. The ODS FeCrAl alloys all contained some residual $\mathrm{Al}$ content which tended to increase with increasing exposure temperature in MA956. The highest residual Al contents were measured in $\mathrm{ODS} \mathrm{Fe}_{3} \mathrm{Al}$ which was expected due to its lower $\mathrm{Cr}$ content ( 2 at.\% versus $\approx 20$ at. \% in $\mathrm{FeCrAl}$ ). However, the surprising result was that the Al profile was not flat in the material (Fig. 2) which needs to be considered in the oxidation lifetime model.

References

[1] W. J. Quadakkers and M. J. Bennett, Mater. Sci. Tech. 10 (1994) 126.

[2] B. A. Pint, P. F. Tortorelli and I .G. Wright, Mater. High Temp. 16, (1999) 1.

[3] I. G. Wright, B. A. Pint and P. F. Tortorelli, Oxid. Met. 55 (2001) 333. 
[4] This research was supported by the Department of Energy's Fossil Energy AR\&TD Program under contract under contract DE-AC05-00OR22725 with UT-Battelle, LLC. The experimental work was assisted by G. Garner, J. W. Jones and H. Longmire.

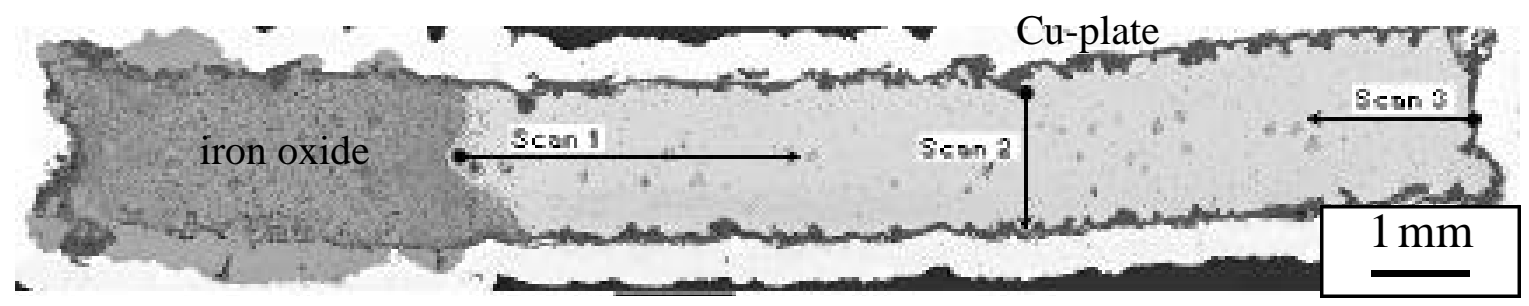

FIG. 1. Light microscopy of polished cross-section of ODS $\mathrm{Fe}_{3} \mathrm{Al}$ (Fe-27at\% Al-2Cr) oxidized for $28 \times 100 \mathrm{~h}$ at $1300^{\circ} \mathrm{C}$. A thick non-uniform oxide covers the specimen except at the left end where breakaway oxidation has begun oxidizing the entire section. Three EPMA line scans are indicated.

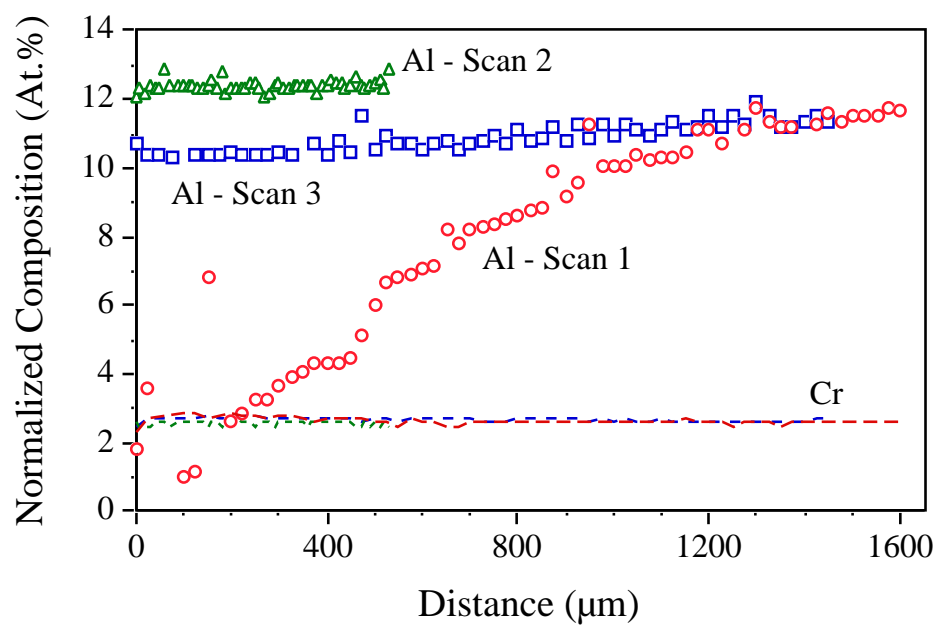

FIG. 2. Residual $\mathrm{Al}$ and $\mathrm{Cr}$ line scans from the specimen indicated in Fig.1. Near the iron oxide, a different profile was detected. The $\mathrm{Cr}$ content was uniform in all three areas.

TABLE 1. Average residual Al content, $C_{b}$, for various specimens oxidized to failure at time $t_{b}$.

\begin{tabular}{|c|c|c|c|c|c|}
\hline Alloy & Thickness & Temperature & $t_{b}(\mathrm{~h})$ & Cycle Frequency & $C_{b}$ (at.\%) \\
\hline \multirow[t]{4}{*}{ MA956 ODS FeCrAl } & $0.5 \mathrm{~mm}$ & $1200^{\circ} \mathrm{C}$ & 350 & $1 \mathrm{~h}$ & $0.2-0.4$ \\
\hline & $0.5 \mathrm{~mm}$ & $1200^{\circ} \mathrm{C}$ & 1100 & $100 \mathrm{~h}$ & 0.3 \\
\hline & $0.75 \mathrm{~mm}$ & $1250^{\circ} \mathrm{C}$ & 500 & $100 \mathrm{~h}$ & $0.3-1.2$ \\
\hline & $0.75 \mathrm{~mm}$ & $1300^{\circ} \mathrm{C}$ & 300 & $100 \mathrm{~h}$ & 1.2 \\
\hline \multirow[t]{4}{*}{ PM2000 ODS FeCrAl } & $40 \mu \mathrm{m}$ & $1050^{\circ} \mathrm{C}$ & 350 & $1 \mathrm{~h}$ & 0.4 \\
\hline & $40 \mu \mathrm{m}$ & $1100^{\circ} \mathrm{C}$ & 125 & $1 \mathrm{~h}$ & 0.3 \\
\hline & $1.7 \mathrm{~mm}$ & $1200^{\circ} \mathrm{C}$ & 3950 & $1 \mathrm{~h}$ & 0.5 \\
\hline & $1.6 \mathrm{~mm}$ & $1300^{\circ} \mathrm{C}$ & 3100 & $1 \mathrm{~h}$ & 0.4 \\
\hline \multirow[t]{3}{*}{$\mathrm{FeCrAl}+\mathrm{Y}$ or $\mathrm{Ce} / \mathrm{La}$} & $60 \mu \mathrm{m}$ & $1050^{\circ} \mathrm{C}$ & 2100 & $1 \mathrm{~h}$ & 0 \\
\hline & $60 \mu \mathrm{m}$ & $1100^{\circ} \mathrm{C}$ & 750 & $1 \mathrm{~h}$ & 0 \\
\hline & $1.5 \mathrm{~mm}$ & $1200^{\circ} \mathrm{C}$ & 8800 & $1 \mathrm{~h}$ & 0 \\
\hline \multirow[t]{2}{*}{ ORNL ODS $\mathrm{Fe}_{3} \mathrm{Al}$} & $1.5 \mathrm{~mm}$ & $1200^{\circ} \mathrm{C}$ & 3950 & $1 \mathrm{~h}$ & $9.2-10.8$ \\
\hline & $1.6 \mathrm{~mm}$ & $1300^{\circ} \mathrm{C}$ & 2800 & $100 \mathrm{~h}$ & $11.5-12.4$ \\
\hline
\end{tabular}

